\title{
Effect of calcium salts of fatty acids on the nutritive value of diets, feeding behavior, and serum blood parameters of lactating Saanen goats grazing on stargrass
}

\section{Ludmila Couto Gomes ${ }^{1}$, Claudete Regina Alcalde ${ }^{1}$, Ulysses Cecato ${ }^{1}$, Gracielle Caroline Mari ${ }^{1}$, Sérgio Mangano de Almeida Santos ${ }^{1}$, Jessyka Guedes Mazziero'}

${ }^{1}$ Universidade Estadual de Maringá, Departamento em Zootecnia, Maringá, PR, Brazil.

\begin{abstract}
The objective of this study was to determine effects of the addition of calcium salts of fatty acids (CSFA) to the concentrate on the intake and digestibility of dry matter and nutrients and the grazing behavior of lactating Saanen goats. Five multiparous goats in their third lactation and four primiparous goats were used. The animals were distributed into two Latin square designs, which, for the multiparous goats was $5 \times 5$, with five treatments $(0 \%, 1.5 \%, 3.0 \%, 4.5 \%$, and $6.0 \%$ CSFA); and for the primiparous goats was $4 \times 4$, with four treatments $(0 \%, 1.5 \%, 3.0 \%$, and $4.5 \%$ CSFA). The addition of CSFA to the concentrate of lactating Saanen goats did not influence the time spent grazing, ruminating, or lying for multiparous goats. However, for primiparous goats, for the time spent grazing, there was a negative quadratic effect with the addition of CSFA to the concentrate. The treatments did not affect the intakes of dry matter, organic matter, crude protein, neutral detergent fiber, total carbohydrates, non-fiber carbohydrates, or total digestible nutrients for multiparous goats. No effects were observed on nutrient digestibility, except for crude protein and the ether extract, which increased the energy values of the diets with $3.5 \%$ CSFA. For primiparous goats, no effects were observed on intake or digestibility. Addition of CSFA can be used as an alternative to feed primiparous goats in grassland when the grazing time is a factor limiting intake. Addition of up to $3.5 \%$ of CSFA increases the energy value of diets for multiparous goats. These results suggest that calcium salts of fatty acids is an alternative energy supplement to feed lactating goats.
\end{abstract}

Key Words: dairy goats, grazing behavior, n-alkanes, rumen-inert fat, soybean oil, tropical climate

\section{Introduction}

Grassland livestock systems are an alternative to produce quality products at competitive prices (Branco et al., 2002). These systems can improve production indices while considering the economic, social, and environmental sustainability of the production process. Brazil has the eighth largest herd of small ruminants, sheep, and goats in the world (FAO, 2012). That reinforces the importance of new studies on feeding goats in Brazilian conditions for the future of nutrition systems and increasing information about tropical environments. Further, scientific journals have published few studies about specialized milk goats raised in grasslands and intensive management.

In general, adding lipids to the diet of lactating animals is an alternative to increase the diet energy density and improve nutrient digestibility and the performance of

Received October 1, 2015 and accepted June 24, 2016. Corresponding author: ludmilagomes@zootecnista.com.br http://dx.doi.org/10.1590/S1806-92902016000800007

Copyright (c) 2016 Sociedade Brasileira de Zootecnia. This is an Open Access article distributed under the terms of the Creative Commons Attribution License (http://creativecommons.org/licenses/by/4.0/), which permits unrestricted use, distribution, and reproduction in any medium, provided the original work is properly cited. lactating animals (Palmquist and Mattos, 2011). In addition, lipids improve fat-soluble vitamin absorption, supply fatty acids to the membranes of tissues, act as precursors of metabolic pathways, and increase certain fatty acids in milk fat, especially polyunsaturated fatty acids (Palmquist and Mattos, 2011). However, depending on the amount supplied, the degree of unsaturation and the degree of rumenprotected lipids, reduced performance can occur owing to the decreased activity of cellulolytic microorganisms, with a consequent reduction in fiber digestibly (Palmquist and Mattos, 2011).

The addition of rumen-inert lipid in the form of calcium salts of fatty acids (CSFA) was proposed by Jenkins and Palmquist (1982). The CSFA is inert in the rumen and is dissociated in the acidic conditions of the abomasum. Among the benefits of CSFA is the possibility of increasing the energy content of the diet without influencing fiber digestibility, thereby allowing high levels of inclusion in ruminant diets (Baldin et al., 2013). In this sense, CSFA is interesting, because it does not change ruminal fermentation (Sirohi et al., 2010) and also improves milk quality (Souza et al., 2014). Thus, CSFA is an energy supplement that in combination with other foods can increase the dry matter intake providing good availability of nutrients for 
satisfactory responses in females for milk production. However, when CSFA is included in larger proportion in animal diets, its intake can be influenced. Sanz Sampelayo et al. (2002) reported that goats refused concentrate due to the reduced palatability of CSFA.

Thus, while the scientific literature has a high amount of works about the use of CSFA for lactating goats, studies with inclusions below $30 \mathrm{~g}$ day $^{-1}$ and with goats raised in tropical grasslands are scarce. Therefore, the present study aimed to evaluate the effect of CSFA in the concentrate fed to multiparous and primiparous lactating Saanen goats on grazing behavior, the nutritive value of the diet, and serum blood metabolites.

\section{Material and Methods}

The experiment was conducted at an experimental farm in southern Brazil, northwestern region of Paraná State, city of Maringá $\left(23^{\circ} \mathrm{S}\right.$ latitude, $52^{\circ} 20^{\prime} \mathrm{W}$ longitude, $550 \mathrm{~m}$ asl); and the work was conducted in accordance with ethical standards (Project no. 014/2010 - MCT/CNPq Universal). The climate, according to the classification of KöppenGeiger (Peel et al., 2007), is characterized as mesothermal Cfa - humid subtropical. The average monthly values of the meteorological data - maximum and minimum temperature $\left({ }^{\circ} \mathrm{C}\right)$, air relative humidity $(\%)$ in the morning and afternoon, raining days, and total precipitation $(\mathrm{mm})$ at the experimental farm - are available on the following website: http://www.fei.uem.br/.

Five multiparous Saanen goats (five years old) on their third lactation $(57.0 \pm 2.7 \mathrm{~kg}$ body weight) and four primiparous Saanen goats (three years old; $54.0 \pm 1.8 \mathrm{~kg}$ body weight) were used. The goats had an average of $78 \pm 10$ days in milk at the beginning of the experiment and an average milk yield of $2.8 \pm 0.1 \mathrm{~kg}^{-1 a y^{-1}}$ and $2.7 \pm 0.1 \mathrm{~kg}$ $\mathrm{day}^{-1}$ for multiparous and primiparous goats, respectively. Goats were distributed into two Latin square designs with an experimental period of 21 days, including 14 days for adaptation and seven days for data collection. The Latin square design was $5 \times 5$, with five treatments $(0 \%, 1.5 \%$, $3.0 \%, 4.5 \%$, and $6.0 \%$ CSFA) for the multiparous goats; and a $4 \times 4$ Latin square design with four treatments for primiparous goats $(0 \%, 1.5 \%, 3.0 \%$, and $4.5 \%$ CSFA). The experiment with primiparous and multiparous goats was conducted at the same time.

Pelleted concentrate was composed of ground corn, soybean meal, a mineral-vitamin supplement for goats, salt, and rumen-inert fat in the form of CSFA from a commercially available product derived from soybean oil (Lactoplus $^{\circledR}$ from Dalquim Chemical Industry Ltd.; with
$1.94 \mathrm{~g} \mathrm{~g}^{-1}$ total digestible nutrients, $820 \mathrm{~g} \mathrm{~kg}^{-1}$ ether extract, $100 \mathrm{~g} \mathrm{~kg}^{-1}$ calcium, $260 \mathrm{~g} \mathrm{~kg}^{-1}$ oleic acid, and $420 \mathrm{~g} \mathrm{~kg}^{-1}$ linoleic acid) at the set levels of inclusion $(0 \%, 1.5 \%$, $3.0 \%, 4.5 \%$, and $6.0 \%$ of the concentrate) (Table 1 ). The amount of concentrate offered to the goats was established at $1.00 \mathrm{~kg} \mathrm{day}^{-1}$ as feed, representing half of the estimated nutritional requirements of Saanen goats (NRC, 2007) with an average body weight of $60.0 \mathrm{~kg}$ and a milk yield of $3.00 \mathrm{~kg} \mathrm{day}^{-1}$ with $3.5 \%$ fat.

Goats were milked manually twice daily $(7.30 \mathrm{~h}$ and $15.30 \mathrm{~h}$ ). The goats remained in the grassland for approximately seven hours $(8.00 \mathrm{~h}$ to $15: 30 \mathrm{~h})$. After the afternoon milking, goats were fed the concentrate and were housed in individual pens for the evening and overnight. The goats had free access to water in the grassland and pens.

From day 10 to 19 , a cellulose capsule of synthetic paired chain $n$-alkane $\left(\mathrm{C}_{32} \mathrm{H}_{66}\right.$, Dotriacontane, $97 \%$ purity, ref. no. D223107, Sigma-Aldrich Corp., St Louis, MO, USA) was inserted into the rumen by an oral probe twice daily at $08.00 \mathrm{~h}$ and $16.00 \mathrm{~h}$, supplying a total of $80 \mathrm{mg}$ of $\mathrm{C}_{32} \mathrm{H}_{66} /$ day.

Table 1 - Ingredients, chemical composition, and in vitro digestibility of the concentrate

\begin{tabular}{|c|c|c|c|c|c|}
\hline \multirow{2}{*}{ Composition } & \multicolumn{5}{|c|}{ Level of calcium salts of fatty acids ${ }^{1}$} \\
\hline & $0.0 \%$ & $1.5 \%$ & $3.0 \%$ & $4.5 \%$ & $6.0 \%$ \\
\hline \multicolumn{6}{|l|}{ Ingredient ( $\left.\mathrm{g} \mathrm{kg}^{-1} \mathrm{DM}\right)$} \\
\hline Ground corn & 695 & 676 & 658 & 639 & 621 \\
\hline Soybean meal & 280 & 284 & 287 & 291 & 294 \\
\hline $\begin{array}{l}\text { Calcium salts of } \\
\text { fatty acids }\end{array}$ & & 15.0 & 30.0 & 45.0 & 60.0 \\
\hline Mineral-vitamin supplement ${ }^{3}$ & 20.0 & 20.0 & 20.0 & 20.0 & 20.0 \\
\hline Salt & 5.00 & 5.00 & 5.00 & 5.00 & 5.00 \\
\hline \multicolumn{6}{|c|}{ Chemical composition ( $\left.\mathrm{g} \mathrm{kg}^{-1} \mathrm{DM}\right)$} \\
\hline Dry matter $\left(\mathrm{g} \mathrm{kg}^{-1}\right)$ & 915 & 916 & 921 & 922 & 926 \\
\hline Organic matter & 951 & 948 & 945 & 943 & 940 \\
\hline Ash & 48.8 & 51.7 & 55.0 & 56.6 & 59.8 \\
\hline Calcium & 3.70 & 4.80 & 5.60 & 6.60 & 7.10 \\
\hline Phosphorus & 4.70 & 4.80 & 4.80 & 4.80 & 4.90 \\
\hline Crude protein & 188 & 189 & 195 & 189 & 183 \\
\hline Ether extract ${ }^{4}$ & 31.7 & 43.5 & 55.4 & 67.2 & 79.0 \\
\hline Neutral detergent fiber & 107 & 103 & 100 & 112 & 115 \\
\hline Non-fiber carbohydrates & 624 & 616 & 594 & 575 & 563 \\
\hline Total carbohydrates & 731 & 719 & 694 & 687 & 678 \\
\hline \multicolumn{6}{|l|}{ In vitro digestibility $\left(\mathrm{g} \mathrm{g}^{-1}\right)$} \\
\hline Dry matter & 0.854 & 0.854 & 0.848 & 0.842 & 0.848 \\
\hline Organic matter & 0.879 & 0.879 & 0.863 & 0.864 & 0.867 \\
\hline Gross energy (Mcal kg-1) & 3.87 & 3.95 & 3.99 & 4.07 & 4.09 \\
\hline \multicolumn{6}{|c|}{ 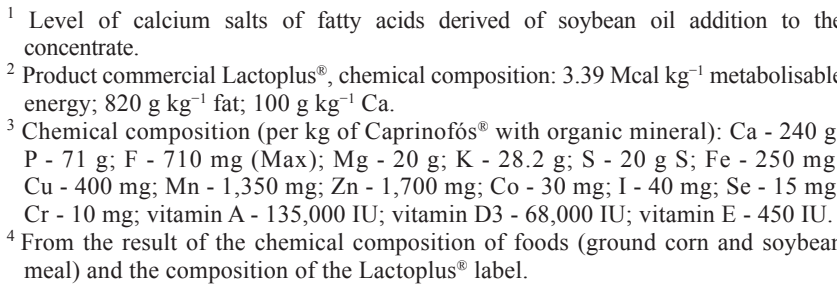 } \\
\hline
\end{tabular}


For grazing of primiparous and multiparous goats, an area of one hectare (1 ha) was used with stargrass (Cynodon nlemfuensis) maintained by continuous stocking (Table 2). The grassland was fertilized and corrected through physical and chemical analysis of the soil and grass demand. Fertilizer was applied at an N-P-K ratio of 8.00 $\mathrm{kg} \mathrm{ha}^{-1}$ nitrogen, $67.0 \mathrm{~kg} \mathrm{ha}^{-1}$ phosphorus, and $70.0 \mathrm{~kg} \mathrm{ha}^{-1}$ potassium (200 kg of N-P-K fertilizer 4-20-20, $150 \mathrm{~kg}$ of single superphosphate, and $50.0 \mathrm{~kg}$ of potassium chloride) in September 2011, which was distributed by broadcasting 30 days before the input of goats. The grazing period was October 82011 to January 202012.

Samples of the forage for chemical analysis and manual separation of the morphological components (leaf blades, stems and sheaths, and dead material) were collected once in each experimental period; to ensure random sampling, one $1.00 \mathrm{~m}^{2}$ wire square was thrown eight times in the paddock and the grass was cut $15.0 \mathrm{~cm}$ above the ground. Samples of forage to determine total forage mass were cut close to the soil. The sward height was measured with a wooden ruler graduated in centimeters at 20 random points. For the chemical analysis, samples of concentrate were taken during each experimental period and pooled.

Fecal grab samples were taken twice daily at $8.00 \mathrm{~h}$ and $16.00 \mathrm{~h}$ from day 15 to 20 and a portion (about $30 \mathrm{~g}$ ) was dried for $48 \mathrm{~h}$ at $55^{\circ} \mathrm{C}$ and composited per goat within period for later chemical analysis.

Samples of forage and feces from each period were oven-dried $\left(55^{\circ} \mathrm{C}\right.$ for $\left.72 \mathrm{~h}\right)$, then ground through a $1-\mathrm{mm}$

Table 2 - Chemical composition, in vitro digestibility, and forage mass of stargrass (Cynodon nlemfuensis)

\begin{tabular}{lcc}
\hline & Stargrass & SDM \\
\hline Chemical composition $\left(\mathrm{g} \mathrm{kg}^{-1} \mathrm{DM}\right)$ & & \\
Dry matter $\left(\mathrm{g} \mathrm{kg}^{-1}\right)$ & 339 & 16.1 \\
Organic matter & 943 & 3.51 \\
Ash & 57.3 & 3.51 \\
Calcium & 2.04 & 0.05 \\
Phosphorus & 2.26 & 0.31 \\
Crude protein & 109 & 9.34 \\
Ether extract & 15.1 & 0.98 \\
Neutral detergent fiber & 656 & 39.3 \\
Total carbohydrates & 819 & 13.9 \\
Non-fiber carbohydrates & 163 & 35.0 \\
In vitro digestibility (g g & \\
Dry matter & & \\
Organic matter & 0.59 & 0.01 \\
Sward height (m) & 0.64 & 0.02 \\
Forage mass (kg DM ha $\left.{ }^{-1}\right)$ & 0.26 & 0.06 \\
Forage mass & & \\
Forage mass (above 0.15 m) & 3.54 & 0.61 \\
$\quad$ Leaf blade & 392 & 312 \\
Stem and sheath & 338 & 129 \\
$\quad$ Leaf:stem ratio & 516 & 182 \\
\hline SDM - standard deviation of the mean; DM - dry & 0.67 & 0.17 \\
\hline
\end{tabular}

SDM - standard deviation of the mean; DM - dry matter. screen sieve in a Wiley mill (MA340 Marconi ${ }^{\circledR}$, Piracicaba, SP, Brazil). The concentrate was ground through a 1-mm sieve screen in a hammer mill (Solotest ${ }^{\mathbb{}}$, São Paulo, SP, Brazil). Dry matter was determined according to AOAC (1998) method no. 934.01. Ash was determined by combustion in a muffle furnace according to method no. 942.05 (AOAC, 1998). Calcium and phosphorus were analyzed using acid digestion with nitric and perchloric acid (1:2). After that, they were filtered to obtain a mineral solution. Calcium and phosphorus readings were obtained using atomic absorption (GBC 932 AA spectrophotometer in an air-acetylene flame) and colorimetry (Shimadzu UV-1601 UV-Visible spectrophotometer, Kyoto, Japan) (AOAC, 1990). Total nitrogen (TN) was evaluated using a Tecnal TE-036/1 apparatus (Tecnal ${ }^{\circledR}$, Piracicaba, SP, Brazil) following AOAC (1998) method no. 988.05 and crude protein $(\mathrm{CP})$ was estimated as $\mathrm{TN} \times 6.25$. The ether extract (EE) was assessed using a Tecnal TE-044/1 apparatus (Tecnal ${ }^{\circledR}$, Piracicaba, SP, Brazil) according to method no. 920.39 (AOAC, 1998). The neutral detergent fiber (NDF) was evaluated as described by Van Soest et al. (1991) without the use of sodium sulfite and with the inclusion of heat-stable $\alpha$-amylase (alpha-amylase Termamyl 2x, Tecnoglobo ${ }^{\circledR}$, Curitiba, PR, Brazil). Total carbohydrates (TC) and total digestible nutrients (TDN) were estimated according to equations described by Sniffen et al. (1992). The method used to calculate feed energy values $\left(\mathrm{Mcal} \mathrm{\textrm {kg } ^ { - 1 }}\right)$ using digestible energy (DE), metabolizable energy (ME), and net energy for lactation $\left(\mathrm{NE}_{\mathrm{L}}\right)$ was applied using the following equations (NRC, 2007): $\mathrm{DE}=0.04409 \times$ $\mathrm{TDN}(\%) ; \mathrm{ME}=1.01 \times \mathrm{DE}-0.45 ;$ and $\mathrm{NE}_{\mathrm{L}}=0.0245 \times$ TDN (\%) - 0.12. Gross energy content was determined by combustion in an adiabatic bomb calorimeter (Parr Instrument Co.AC $720^{\circledR}$, Parr Instrument Company, Moline, IL, USA).

The in vitro dry matter and organic matter digestibility (IVDMD and IVOMD, respectively) of the five concentrates $(0 \%, 1.5 \%, 3.0 \%, 4.5 \%$, and $6.0 \%$ CSFA) and stargrass were determined according to the procedure described by Tilley and Terry (1963) using an artificial rumen (ANKOM Technology ${ }^{\circledR}$, Macedon, New York, USA) according to Santos et al. (2000). The concentrates offered to the animals and the stargrass were incubated separately. The rumen fluid used as an inoculum was drawn from the rumen of three cannulated crossbred $1 / 2$ Boer $\times 1 / 2$ Saanen goats fed stargrass and transferred into pre-warmed thermos bottles. The in vitro digestibility (IVD) was calculated as the difference between the incubated and residual amount of feed, using the following equation: IVD $=100-[(\mathrm{W} 3-$ (W1 $\times$ W4) $\times 100 /$ W2], in which W1 is the empty filter weight; 
W2 is the sample weight; W3 is the filter final weight; and W4 is the filter blank correction.

The grazing behavior of lactating Saanen goats was measured by observing each goat with identification from the 16th to 18th day of each experimental period. The goats were assessed by direct observation three days per period, during the grazing period (six hours per day), with observations made every 10 min (Carvalho et al., 2007), totaling 108 observations per goat per period, consequently totaling 2700 observations for multiparous goats and 1728 observations for primiparous goats. The activities performed by the goats were assessed by the recording, according to the times spent grazing, ruminating standing and lying, and resting standing and lying. The behavioral activities were considered mutually exclusionary; in other words, for every record, each animal was classified in only one activity.

On the days used for measuring the grazing behavior of lactating Saanen goats, environmental variables were recorded (Table 3), including wind speed, air temperature, air relative humidity, and dew point temperature, which were collected using a hygro-thermo-anemometer (Kestrel $3000^{\circledR}$, Nielsen-Kellerman, Boothwyn, PA, USA). The black-globe temperature was obtained by a black plastic ball with $15 \mathrm{~cm}$ diameter and an alcohol column thermometer (black-globe thermometer). During data collection, the equipment was positioned $0.80 \mathrm{~m}$ above the soil, simulating the height at the goat dorsum. The climate data collection was performed simultaneously with measuring feeding behavior, every hour, during the six hours of grazing.

For the evaluation of the environment, the blackglobe humidity index (BGHI) was used, as proposed by Buffington et al. (1981), and used to determine the radiant thermal load (CTR), as proposed by Esmay (1969), using the following equations:

$$
\mathrm{BGHI}=\mathrm{BG}_{\mathrm{T}}+0.36 \mathrm{DP}_{\mathrm{T}}+41.5 ; \mathrm{CTR}\left(\mathrm{W} \cdot \mathrm{m}^{-2}\right)=\sigma \mathrm{MR}_{\mathrm{T}}^{4}
$$

$\mathrm{MR}_{\mathrm{T}}=100\left(2.51 \mathrm{~W}_{\mathrm{S}} 0.5\left(\mathrm{BG}_{\mathrm{T}}-\mathrm{A}_{\mathrm{T}}\right)+\left(\left(\mathrm{BG}_{\mathrm{T}}+273.15\right) / 100\right)^{4}\right)^{0.25}$, in which $\mathrm{BG}_{\mathrm{T}}=$ black-globe temperature $\left({ }^{\circ} \mathrm{C}\right) ; \mathrm{DP}_{\mathrm{T}}=$ dew point temperature $\left({ }^{\circ} \mathrm{C}\right) ; \sigma=$ Stefan-Boltzmann constant $\left(5.67 \times 10^{-8} \mathrm{~W} \mathrm{~m}^{-2} \mathrm{~K}^{-4}\right) ; \mathrm{MR}_{\mathrm{T}}=$ mean radiant temperature $\left({ }^{\circ} \mathrm{K}\right) ; \mathrm{A}_{\mathrm{T}}=$ air temperature $\left({ }^{\circ} \mathrm{C}\right)$; and $\mathrm{W}_{\mathrm{S}}=$ wind speed $\left(\mathrm{m} \mathrm{s}^{-1}\right)$.

To determine the serum blood biochemical composition, i.e., glucose cholesterol, triglycerides, urea, calcium, and phosphorus, blood was sampled after the morning milking, every 17 th day of each experimental period. Blood samples were collected by puncture of the jugular vein, using disposable hypodermic needles, and the blood was placed in test tubes containing $10 \mathrm{~mL}$. After $15 \mathrm{~min}$ at $3,400 \mathrm{rpm}$ at room temperature in a centrifuge (Tecnal 2006-BABY I ${ }^{\circledR}$, Piracicaba, SP, Brazil), serum

\begin{tabular}{|c|c|c|c|c|c|}
\hline Environmental variable & Period 1 & Period 2 & Period 3 & Period 4 & Period 5 \\
\hline \multicolumn{6}{|l|}{ Air temperature $\left({ }^{\circ} \mathrm{C}\right)$} \\
\hline Maximum & 29.7 & 28.4 & 32.4 & 29.7 & 32.8 \\
\hline Minimum & 23.9 & 23.9 & 24.0 & 25.7 & 21.4 \\
\hline \multicolumn{6}{|c|}{ Black-globe temperature $\left({ }^{\circ} \mathrm{C}\right)$} \\
\hline Maximum & 40.3 & 41.7 & 48.0 & 44.0 & 44.0 \\
\hline Minimum & 34.0 & 31.7 & 34.7 & 36.3 & 30.3 \\
\hline \multicolumn{6}{|l|}{ Air relative humidity (\%) } \\
\hline Maximum & 61.0 & 68.0 & 66.0 & 51.0 & 81.0 \\
\hline Minimum & 46.0 & 49.0 & 38.0 & 34.0 & 53.0 \\
\hline Average days & 53.0 & 58.7 & 51.4 & 40.9 & 68.7 \\
\hline \multicolumn{6}{|l|}{ Wind speed $\left(\mathrm{m} \mathrm{s}^{-1}\right)$} \\
\hline Maximum & 1.7 & 1.8 & 1.9 & 1.8 & 2.0 \\
\hline Minimum & 81.6 & 79.2 & 82.4 & 83.3 & 78.1 \\
\hline Average days & 84.3 & 86.1 & 88.6 & 87.9 & 88.9 \\
\hline \multicolumn{6}{|c|}{ Radiant thermal load $\left(\mathrm{W} \mathrm{m}^{-2}\right)$} \\
\hline Maximum & 666 & 681 & 615 & 733 & 741 \\
\hline Minimum & 526 & 528 & 571 & 550 & 570 \\
\hline Average days & 600 & 613 & 642 & 633 & 655 \\
\hline
\end{tabular}

Table 3 - Mean values of environmental variables in each experimental period

Period 1 - October 8 to October 28, 2011; Period 2 - October 29 to November 18, 2011; Period 3 - November 19 to December 9, 2011 ; Period 4 - December 10 to December 30 , 2011; Period 5 - December 31, 2011 to January 20, 2012. 
was obtained from the blood, placed in Eppendorf tubes, and frozen for subsequent analyses.

Serum glucose, cholesterol, triglycerides, urea, calcium, and phosphorus concentrations were analyzed using commercial kits (glucose-PP CAT. 434, cholesterolPP CAT. 460, triglycerides-PP CAT. 459, urea-PP CAT. 427, calcium-PP CAT 448, phosphorus-PP CAT 342; Gold Analisa Diagnostica ${ }^{\circledR}$, Belo Horizonte, MG, Brazil) in a spectrophotometer (Shimadzu UV-1601 UV-Visible Spectrophotometer ${ }^{\circledR}$, Kyoto, Japan).

Milk samples were collected on the 15th day of each period from each goat from two consecutive milkings and pooled on a yield basis. For the chemical composition determination, milk samples were stored at $4{ }^{\circ} \mathrm{C}$ with a preservative (2-bromo-2-nitropropane-1,3-diol) until analyzed for fat, protein, lactose and total solids by infrared spectroscopy (Bentley model 2000 ${ }^{\circledR}$; Bentley Instrument Inc., Chaska, MN, USA). The milk yield was corrected to $4.0 \%$ fat according to the NRC (2007) using the NRC (2001) equation.

The extraction and determination of the $n$-alkane content in forage and feces were performed according to Mayes et al. (1986), modified by Vulich et al. (1995); the analysis was based on direct saponification of samples.

A gas chromatograph (GC Agilent $7890 \mathrm{~A}^{\circledR}$, Palo Alto, CA, USA) equipped with a mass selective detector (MS Agilent 5975C ${ }^{\circledR}$, Palo Alto, CA, USA) was used to identify and quantify the $n$-alkanes. The column used was a Zebron $^{\mathrm{TM}} \mathrm{ZB}-5 \mathrm{MS}(30 \mathrm{~m} \times 0.32 \mathrm{~mm} \times 0.25 \mu \mathrm{m}$, absorbent composed of $5 \%$ phenyl-arylene- $95 \%$ polydimethylsiloxane (Phenomenex Inc., Torrance, CA, USA). The carrier gas was $\mathrm{H}_{2}$ at a constant flow of $1 \mathrm{~mL} / \mathrm{min}$. Temperature gradients were controlled for the injector $\left(300{ }^{\circ} \mathrm{C}\right)$ and the column $\left(130^{\circ} \mathrm{C}\right.$ for $1 \mathrm{~min} ; 10^{\circ} \mathrm{C} / \mathrm{min}$ until $210^{\circ} \mathrm{C}$, and $5^{\circ} \mathrm{C} / \mathrm{min}$ to $310^{\circ} \mathrm{C}$ hold for $1 \mathrm{~min} ; 32 \mathrm{~min}$ ). The MS source temperature was set at $250^{\circ} \mathrm{C}$ and the temperature of the MS quadrupole was $120^{\circ} \mathrm{C}$. With a microliter syringe, $1 \mu \mathrm{L}$ of the sample was injected with a split ratio of 1:10.

The gas chromatograph process was calibrated with an external standard solution of a synthetic $n$-alkanes mix $\mathrm{C}_{24}, \mathrm{C}_{26}, \mathrm{C}_{28}, \mathrm{C}_{32}, \mathrm{C}_{34}$, and $\mathrm{C}_{36}$ (Tetracosane $99 \%$ purity ref. no. T8752, Hexacosane $99 \%$ purity ref no. 241687 , Dotriacontane $97 \%$ purity ref. no. D223107, Tetratriacontane $98 \%$ purity ref. no. 287261 , Hexatriacontane $98 \%$ purity ref. no. 52919; Sigma-Aldrich Corp., St Louis, MO, USA). The chromatography peak areas corresponding to each $n$-alkane were determined by MSD ChemStation Data Analysis $^{\circledR}$ (Agilent Technologies, Palo Alto, CA, USA). The identified peaks were converted to $n$-alkane quantity with regard to each peak area and the internal standard $\mathrm{C}_{34}$, and then calculated as $\mathrm{mg} \mathrm{g}^{-1}$ of DM.

The dry matter intake (DMI) was estimated in forage and feces based on the concentration of $n$-alkanes naturally present in the diet $\left(\mathrm{C}_{31}\right.$ and $\left.\mathrm{C}_{33}\right)$ and the homologue $\mathrm{C}_{32}$, which was orally administered. The estimated values of DMI with the $\mathrm{C}_{31}: \mathrm{C}_{32}$ and $\mathrm{C}_{33}: \mathrm{C}_{32}$ pairs were obtained by the equation of Mayes et al. (1986). The DM digestibility was estimated by the following equation: $\mathrm{DMD}=1-(\mathrm{ID} / \mathrm{IF}) \times 100$; in which DMD = dry matter digestibility coefficient by $n$-alkane; ID $=$ internal content of $n$-alkane in the forage; and IF $=$ internal content of $n$-alkane in the feces.

The experiment was analyzed according to a $5 \times 5$ Latin square design for multiparous goats and a $4 \times 4$ Latin square design for primiparous goats, using the procedure of Sisvar (version 5.3, build 86, Federal University of Lavras, MG, Brazil) according to the general model below:

$$
\mathrm{Y}_{i j k}=\mu+\alpha_{i}+\beta_{j}+\tau_{k}+e_{i j k},
$$

in which $Y_{i \mathrm{ijk}}=$ dependent variable; $\mu=$ overall constant; $\alpha_{i}=$ effect of concentrate $i ; \beta_{j}=$ effect of period $j ; \tau_{l}=$ effect of animal $l$; and $e_{i j k}=$ random error.

The data of nutritive value of diets, feeding behavior, and serum blood parameters were assessed by variance analysis (ANOVA) followed by linear and/or quadratic effects of addition of CSFA to the concentrate of lactating Saanen goats. The significance $(\alpha=0.05)$ of type-I error was adopted as the critical value of the probability of type-I error.

\section{Results}

There was no significant effect on the intakes of dry matter, organic matter, crude protein, neutral detergent fiber, total carbohydrates, non-fiber carbohydrates, or total digestible nutrients for multiparous grassland Saanen goats fed the concentrates containing CSFA (Table 4). However, the ether extract intake increased linearly with the addition of CSFA to the concentrate. The digestibility coefficients of dry matter, organic matter, neutral detergent fiber, total carbohydrates, and non-fiber carbohydrates were not changed by CSFA in the concentrates. However, a significant effect of crude protein and ether extract digestibility coefficients led to an increase in the energy value of the diet, total digestible nutrients, digestible energy, metabolizable energy, and net energy for lactation.

When primiparous lactating Saanen goats were fed CSFA, there was no significant effect on the intake and digestibility coefficients of dry matter and nutrients; 
consequently, the energy value of diets was not changed. However, the inclusion of CSFA changed the ether extract intake and digestibility coefficients (Table 5).

The addition of rumen-inert fat as CSFA to the concentrate of multiparous grassland Saanen goats had no effect on their milk yield $(2.80 \pm 0.10 \mathrm{~kg})$. Similar to multiparous goats, the treatment of primiparous Saanen goats had no effect on milk yield $\left(2.67 \pm 0.09 \mathrm{~kg} \mathrm{day}^{-1}\right)$.

The addition of CSFA to the concentrate fed to lactating Saanen goats did not influence the spent time grazing, ruminating, or lying for multiparous goats (Table 6). However, for primiparous goats, there was a negative quadratic effect for time spent grazing due to addition of CSFA to the concentrate.

The treatments did not affect the serum blood concentration of glucose, triglycerides, urea, calcium, or phosphorus in Saanen goats, either multiparous or primiparous. However, there was a liner increase in the cholesterol concentration when multiparous goats were fed CSFA (Table 7).

\section{Discussion}

The air temperature during the grazing period was within the comfort zone for goats, i.e., 20 to $30{ }^{\circ} \mathrm{C}$ (Baêta and Souza, 2010), except for two experimental periods (periods 3 and 5), when the maximum environmental temperature exceeded $30^{\circ} \mathrm{C}$. However, in this study, the air temperature did not exceed the upper critical temperature for goats $\left(35^{\circ} \mathrm{C}\right)$.

The air relative humidity ranged from 34 to $81 \%$. According to Baêta and Souza (2010), the ideal relative

Table 4 - Dry matter and nutrient intake and total apparent digestibility of multiparous Saanen goats in grassland fed experimental diets

\begin{tabular}{|c|c|c|c|c|c|c|c|c|c|}
\hline & \multicolumn{5}{|c|}{ Level of calcium salts of fatty acids ${ }^{1}$} & \multirow{2}{*}{ SEM } & \multicolumn{3}{|c|}{ P-value } \\
\hline & $0.0 \%$ & $1.5 \%$ & $3.0 \%$ & $4.5 \%$ & $6.0 \%$ & & A & $\mathrm{L}$ & Q \\
\hline Body weight & 57.3 & 56.3 & 57.1 & 57.1 & 57.4 & 0.54 & 0.67 & 0.59 & 0.41 \\
\hline \multicolumn{10}{|l|}{ DMI (kg day $\left.{ }^{-1}\right)$} \\
\hline DMI & 1.94 & 1.96 & 2.20 & 1.90 & 2.19 & 0.08 & 0.06 & 0.12 & 0.97 \\
\hline Forage DMI & 1.02 & 1.04 & 1.28 & 0.98 & 1.26 & 0.08 & 0.07 & 0.14 & 0.97 \\
\hline Concentrate DMI & 0.92 & 0.92 & 0.92 & 0.92 & 0.93 & & & & \\
\hline $\mathrm{DMI}\left(\mathrm{BW}^{0.75}\right)$ & 93.6 & 95.4 & 106 & 91.6 & 105 & 4.32 & 0.09 & 0.18 & 0.86 \\
\hline \multicolumn{10}{|c|}{ Nutrient intake $\left(\mathrm{kg} \mathrm{day}^{-1}\right)$} \\
\hline $\mathrm{OM}$ & 1.83 & 1.85 & 2.08 & 1.79 & 2.06 & 0.08 & 0.06 & 0.14 & 0.97 \\
\hline $\mathrm{CP}$ & 0.28 & 0.28 & 0.32 & 0.28 & 0.31 & 0.01 & 0.05 & 0.23 & 0.47 \\
\hline $\mathrm{EE}^{2}$ & 0.04 & 0.06 & 0.07 & 0.08 & 0.09 & 0.001 & $<0.01$ & $<0.01$ & 0.92 \\
\hline NDF & 0.76 & 0.78 & 0.93 & 0.74 & 0.93 & 0.06 & 0.07 & 0.11 & 0.96 \\
\hline $\mathrm{TC}$ & 1.50 & 1.51 & 1.69 & 1.44 & 1.66 & 0.07 & 0.09 & 0.28 & 0.95 \\
\hline NFC & 0.74 & 0.73 & 0.76 & 0.69 & 0.73 & 0.01 & 0.06 & 0.20 & 0.88 \\
\hline TDN & 1.22 & 1.33 & 1.45 & 1.35 & 1.44 & 0.06 & 0.10 & 0.03 & 0.25 \\
\hline \multicolumn{10}{|c|}{ Digestibility coefficient $\left(\mathrm{g} \mathrm{g}^{-1}\right)$} \\
\hline $\mathrm{DM}^{3}$ & 0.62 & 0.68 & 0.65 & 0.69 & 0.63 & 0.02 & 0.05 & 0.59 & 0.03 \\
\hline $\mathrm{OM}^{4}$ & 0.64 & 0.69 & 0.67 & 0.71 & 0.65 & 0.02 & 0.05 & 0.55 & 0.04 \\
\hline $\mathrm{CP}^{5}$ & 0.58 & 0.67 & 0.64 & 0.68 & 0.62 & 0.02 & 0.03 & 0.21 & 0.01 \\
\hline $\mathrm{EE}^{6}$ & 0.60 & 0.73 & 0.75 & 0.84 & 0.81 & 0.02 & $<0.01$ & $<0.01$ & $<0.01$ \\
\hline NDF & 0.50 & 0.56 & 0.55 & 0.59 & 0.53 & 0.02 & 0.06 & 0.57 & 0.52 \\
\hline NFC & 0.82 & 0.84 & 0.80 & 0.84 & 0.80 & 0.02 & 0.26 & 0.31 & 0.53 \\
\hline $\mathrm{TC}$ & 0.66 & 0.70 & 0.67 & 0.71 & 0.65 & 0.02 & 0.09 & 0.93 & 0.07 \\
\hline \multicolumn{10}{|c|}{ Energy value of diets (Mcal kg-1) } \\
\hline TDN $\left(\mathrm{g} \mathrm{g}^{-1}\right)^{7}$ & 0.63 & 0.68 & 0.66 & 0.71 & 0.66 & 0.02 & 0.02 & 0.09 & 0.03 \\
\hline $\mathrm{DE}^{8}$ & 2.77 & 3.01 & 2.90 & 3.14 & 2.89 & 0.08 & 0.02 & 0.09 & 0.03 \\
\hline $\mathrm{ME}^{9}$ & 2.35 & 2.59 & 2.48 & 2.73 & 2.48 & 0.07 & 0.02 & 0.09 & 0.03 \\
\hline $\mathrm{NEL}^{10}$ & 1.54 & 1.67 & 1.61 & 1.75 & 1.61 & 0.04 & 0.02 & 0.09 & 0.03 \\
\hline
\end{tabular}

SEM - standard error of the mean; A - ANOVA; L - linear; Q - quadratic

DMI - dry matter intake; BW - body weight; DM - dry matter; OM - organic matter; CP - crude protein; EE - ether extract; NDF - neutral detergent fiber; NFC - non-fiber carbohydrates; TC - total carbohydrates; TDN - total digestible nutrients; DE - digestible energy; ME - metabolisable energy; NEL - net energy for lactation.

Digestible, metabolisable, and net energy were estimated by NRC (2007) equations.

${ }^{1}$ Level of calcium salts of fatty acids derived from soybean oil addition to the concentrate.

${ }^{2} \mathrm{Y}=0.04+0.01 \mathrm{x} ; \mathrm{r}^{2}=0.99$

${ }^{3} \mathrm{Y}=0.59+0.05 \mathrm{x}-0.01 \mathrm{x}^{2} ; \mathrm{r}^{2}=0.76$

${ }^{4} \mathrm{Y}=0.64+0.03 \mathrm{x} ; \mathrm{r}^{2}=0.80$

${ }^{5} \mathrm{Y}=0.65+0.03 \mathrm{x}-0.004 \mathrm{x}^{2} ; \mathrm{r}^{2}=0.48$

${ }^{6} \mathrm{Y}=0.63+0.03 \mathrm{x}-0.005 \mathrm{x}^{2} ; \mathrm{r}^{2}=0.47$

${ }^{7} \mathrm{Y}=0.63+0.03 \mathrm{x}-0.004 \mathrm{x}^{2} ; \mathrm{r}^{2}=0.54$

${ }^{8} \mathrm{Y}=2.78+0.14 \mathrm{x}-0.02 \mathrm{x}^{2} ; \mathrm{r}^{2}=0.54$

${ }^{9} \mathrm{Y}=2.36+0.15 \mathrm{x}-0.02 \mathrm{x}^{2} ; \mathrm{r}^{2}=0.54$

${ }^{10} \mathrm{Y}=1.54+0.08 \mathrm{x}-0.01 \mathrm{x}^{2} ; \mathrm{r}^{2}=0.54$ 
humidity for animal rearing is between 50 and 70\%; thus, the animals spent most part of the grazing period in ideal humidity conditions.

To assess the suitability of thermal comfort of a facility, several indices are used. The black globe humidity index (BGHI), proposed by Buffington et al. (1981), is a more exact indicator of animal comfort, especially when animals are exposed to direct and indirect solar radiation. The average BGHI values were above those of normal conditions $($ average $=87.20 ;$ minimum $=78.10 ;$ and maximum $=93.30)$ according to Baêta and Souza (1997) (BGHI values up to 74.00 define a comfortable situation; 74.00 to 78.00 , an alert situation; 79.00 to 84.00 , a dangerous situation; and over 84 , an emergency).

The dry matter and nutrient intakes were not modified by the addition of CSFA to the concentrates of multiparous or primiparous Saanen goats on a stargrass grassland, which were 2.04 and $2.11 \mathrm{~kg} \mathrm{day}^{-1}$, respectively. Molina (2013) also showed $2.0 \mathrm{~kg} \mathrm{day}^{-1}$ DMI for Saanen goats fed $0,6.25,12.50,18.75$, and $25.0 \mathrm{~g} \mathrm{~kg}^{-1}$ CSFA from soybean oil in the diet. Therefore, for goats fed diets with low percentages of CSFA $(0 \%, 1.5 \%, 3.0 \%, 4.5 \%$, and $6.0 \%$ CSFA in the concentrate), the risks of palatability problems are reduced. Although calcium salts of fatty acids have the characteristic odor of soap, their inclusion in the diets did not restrict the intake of dry matter. Furthermore, pelleting and good mixture of the ingredients are essential to reduce the selection ability and avoid intake reduction. The dry mater intake determines the intake of all other nutrients and, therefore, is considered a limiting factor for ruminant production (Fonseca et al., 2006).

The CSFA in small quantities did not change the rumen environment, since the NDF digestibility was not affected. The CSFA probably did not reduce the rate of cell division and the growth of cellulolytic bacteria, which impairs fiber digestion. Thus, the diets probably provided the same rate of rumen passage and consequently the same dry matter intake.

When compared with other studies in which the goats were kept on a grassland, these results are in agreement.

Table 5 - Dry matter and nutrient intake and total apparent digestibility of primiparous Saanen goats in grassland fed experimental diets

\begin{tabular}{|c|c|c|c|c|c|c|c|c|}
\hline & \multicolumn{4}{|c|}{ Level of calcium salts of fatty acids ${ }^{1}$} & \multirow{2}{*}{ SEM } & \multicolumn{3}{|c|}{ P-value } \\
\hline & $0.0 \%$ & $1.5 \%$ & $3.0 \%$ & $4.5 \%$ & & A & $\mathrm{L}$ & Q \\
\hline Body weight & 54.0 & 53.9 & 53.9 & 54.0 & 0.63 & 0.99 & 0.97 & 0.81 \\
\hline \multicolumn{9}{|c|}{ Dry matter intake $\left(\mathrm{g} \mathrm{day}^{-1}\right)$} \\
\hline DMI & 2.04 & 2.20 & 2.08 & 2.10 & 0.12 & 0.80 & 0.90 & 0.58 \\
\hline Forage DMI & 1.12 & 1.29 & 1.16 & 1.18 & 0.12 & 0.80 & 0.94 & 0.58 \\
\hline Concentrate DMI & 0.92 & 0.91 & 0.92 & 0.92 & & & & \\
\hline DMI (BW $\left.{ }^{0.75}\right)$ & 102 & 111 & 104 & 106 & 5.45 & 0.74 & 0.89 & 0.54 \\
\hline \multicolumn{9}{|c|}{ Nutrient intake $\left(\mathrm{g} \mathrm{day}^{-1}\right)$} \\
\hline $\mathrm{OM}$ & 1.93 & 2.08 & 1.96 & 1.99 & 0.12 & 0.80 & 0.93 & 0.58 \\
\hline $\mathrm{CP}$ & 0.29 & 0.30 & 0.30 & 0.30 & 0.01 & 0.87 & 0.73 & 0.51 \\
\hline $\mathrm{EE}^{2}$ & 0.05 & 0.06 & 0.07 & 0.08 & 0.002 & $<0.01$ & $<0.01$ & 0.58 \\
\hline NDF & 0.83 & 0.94 & 0.85 & 0.87 & 0.08 & 0.79 & 0.90 & 0.60 \\
\hline $\mathrm{TC}$ & 1.59 & 1.72 & 1.59 & 1.61 & 0.10 & 0.78 & 0.86 & 0.59 \\
\hline NFC & 0.76 & 0.78 & 0.74 & 0.73 & 0.02 & 0.48 & 0.26 & 0.59 \\
\hline TDN & 1.29 & 1.48 & 1.30 & 1.42 & 0.07 & 0.24 & 0.51 & 0.60 \\
\hline \multicolumn{9}{|c|}{ Digestibility coefficient $\left(\mathrm{g} \mathrm{g}^{-1}\right)$} \\
\hline DM & 0.63 & 0.67 & 0.61 & 0.66 & 0.02 & 0.22 & 0.66 & 0.86 \\
\hline OM & 0.65 & 0.68 & 0.63 & 0.68 & 0.02 & 0.22 & 0.63 & 0.90 \\
\hline $\mathrm{CP}$ & 0.60 & 0.62 & 0.59 & 0.63 & 0.02 & 0.71 & 0.58 & 0.71 \\
\hline $\mathrm{EE}^{3}$ & 0.63 & 0.71 & 0.75 & 0.80 & 0.03 & 0.04 & $<0.01$ & 0.70 \\
\hline NDF & 0.51 & 0.60 & 0.50 & 0.56 & 0.02 & 0.06 & 0.67 & 0.53 \\
\hline $\mathrm{TC}$ & 0.66 & 0.69 & 0.64 & 0.68 & 0.02 & 0.17 & 0.89 & 0.96 \\
\hline $\mathrm{NFC}$ & 0.81 & 0.79 & 0.78 & 0.81 & 0.02 & 0.69 & 0.91 & 0.28 \\
\hline \multicolumn{9}{|c|}{ Energy values of diets (Mcal kg-1) } \\
\hline TDN $\left(\mathrm{g} \mathrm{g}^{-1}\right)$ & 0.61 & 0.72 & 0.66 & 0.69 & 0.05 & 0.56 & 0.54 & 0.50 \\
\hline $\mathrm{DE}$ & 2.71 & 3.19 & 2.89 & 3.03 & 0.24 & 0.56 & 0.54 & 0.50 \\
\hline $\mathrm{ME}$ & 2.29 & 2.77 & 2.47 & 2.61 & 0.24 & 0.56 & 0.54 & 0.50 \\
\hline NEL & 1.50 & 1.77 & 1.61 & 1.69 & 0.13 & 0.56 & 0.54 & 0.50 \\
\hline
\end{tabular}

SEM - standard error of the mean; A - ANOVA; L - linear; Q - quadratic

DMI - dry matter intake; BW - body weight; DM - dry matter; OM - organic matter; CP - crude protein; EE - ether extract; NDF - neutral detergent fiber; NFC - non-fiber carbohydrates ; TC - total carbohydrates; TDN - total digestible nutrients; DE - digestible energy; ME - metabolisable energy; NEL - net energy for lactation.

Digestible, metabolisable, and net energy were estimated by NRC (2007) equations.

${ }^{1}$ Level of calcium salts of fatty acids derived from soybean oil addition to the concentrate.

${ }^{2}$ Regression equation: $\mathrm{Y}=0.05+0.007 \mathrm{x} ; \mathrm{r}^{2}=0.99$.

${ }^{3}$ Regression equation: $\mathrm{Y}=0.64+0.37 \mathrm{x} ; \mathrm{r}^{2}=0.97$ 
Rufino et al. (2012) supplemented Anglo-Nubian goats with $1.5 \%$ body weight on Tanzania-grass and showed $1.89 \mathrm{~kg}$ day $^{-1}$ DMI. Mancilla-Leytón et al. (2013) observed $1.87 \mathrm{~kg}$ day $^{-1}$ DMI when goats were supplemented with
$0.5 \mathrm{~kg} \mathrm{day}^{-1}$ concentrate in scrublands (158.8 $\mathrm{g} \mathrm{kg}^{-1} \mathrm{CP}$ and $\left.579.4 \mathrm{~g} \mathrm{~kg}^{-1} \mathrm{NDF}\right)$. In this study, the largest amount of concentrate $\left(1.00 \mathrm{~kg} \mathrm{day}{ }^{-1}\right.$ or $1.75 \%$ of body weight) resulted in the greatest dry matter intake (about $150 \mathrm{~g}$ ).

Table 6 - Time spent on different feeding behaviors by multiparous and primiparous lactating Saanen goats

\begin{tabular}{|c|c|c|c|c|c|c|c|c|c|}
\hline \multirow{2}{*}{ Behavior } & \multicolumn{5}{|c|}{ Level of calcium salts of fatty acids ${ }^{1}$} & \multirow{2}{*}{ SEM } & \multicolumn{3}{|c|}{ P-value } \\
\hline & $0.0 \%$ & $1.5 \%$ & $3.0 \%$ & $4.5 \%$ & $6.0 \%$ & & Model & $\mathrm{L}$ & Q \\
\hline \multicolumn{10}{|c|}{ Multiparous goats } \\
\hline \multicolumn{10}{|l|}{ Percentage } \\
\hline Grazing and drinking water & 71.1 & 74.0 & 77.9 & 69.8 & 67.6 & 3.2 & 0.24 & 0.28 & 0.09 \\
\hline Ruminating standing & 4.11 & 4.15 & 4.10 & 2.12 & 3.20 & 1.61 & 0.87 & 0.46 & 0.98 \\
\hline Ruminating lying & 13.1 & 10.8 & 10.7 & 16.1 & 16.3 & 2.79 & 0.42 & 0.19 & 0.35 \\
\hline Resting standing & 6.85 & 7.27 & 5.78 & 8.35 & 8.93 & 1.68 & 0.70 & 0.34 & 0.50 \\
\hline Resting lying & 4.81 & 3.73 & 1.61 & 3.03 & 3.96 & 2.02 & 0.84 & 0.71 & 0.34 \\
\hline \multicolumn{10}{|l|}{ Time $(\mathrm{h})$} \\
\hline Grazing and drinking water & 4.26 & 4.44 & 4.67 & 4.18 & 4.05 & 0.19 & 0.24 & 0.28 & 0.09 \\
\hline Ruminating standing & 0.25 & 0.25 & 0.25 & 0.13 & 0.19 & 0.10 & 0.87 & 0.46 & 0.98 \\
\hline Ruminating lying & 0.79 & 0.65 & 0.64 & 0.99 & 0.98 & 0.18 & 0.42 & 0.19 & 0.35 \\
\hline Resting standing & 0.41 & 0.44 & 0.35 & 0.50 & 0.54 & 0.10 & 0.70 & 0.34 & 0.50 \\
\hline Resting lying & 0.29 & 0.22 & 0.10 & 0.18 & 0.24 & 0.12 & 0.84 & 0.71 & 0.34 \\
\hline \multicolumn{10}{|c|}{ Primiparous goats } \\
\hline \multicolumn{10}{|l|}{ Percentage } \\
\hline Grazing and drinking water ${ }^{2}$ & 82.0 & 74.5 & 77.2 & 79.1 & & 1.03 & 0.01 & 0.26 & $<0.01$ \\
\hline Ruminating standing & 3.98 & 4.00 & 6.01 & 4.68 & & 1.03 & 0.52 & 0.41 & 0.54 \\
\hline Ruminating lying & 8.71 & 12.8 & 13.4 & 12.1 & & 1.95 & 0.40 & 0.26 & 0.22 \\
\hline Resting standing & 4.68 & 7.36 & 3.34 & 4.04 & & 1.72 & 0.44 & 0.47 & 0.59 \\
\hline Resting lying & 0.68 & 1.35 & 0.00 & 0.00 & & 0.64 & 0.45 & 0.29 & 0.62 \\
\hline \multicolumn{10}{|l|}{ Time (h) } \\
\hline Grazing and drinking water ${ }^{3}$ & 4.91 & 4.47 & 4.63 & 4.75 & & 0.06 & 0.01 & 0.26 & $<0.01$ \\
\hline Ruminating standing & 0.24 & 0.24 & 0.36 & 0.28 & & 0.06 & 0.52 & 0.41 & 0.54 \\
\hline Ruminating lying & 0.52 & 0.77 & 0.81 & 0.73 & & 0.12 & 0.40 & 0.26 & 0.22 \\
\hline Resting standing & 0.28 & 0.44 & 0.20 & 0.24 & & 0.10 & 0.44 & 0.47 & 0.59 \\
\hline Resting lying & 0.04 & 0.08 & 0.00 & 0.00 & & 0.04 & 0.45 & 0.29 & 0.62 \\
\hline
\end{tabular}

SEM - standard error of the mean; L - linear; Q - quadratic.

${ }^{1}$ Level of calcium salts of fatty acids derived from soybean oil addition to the concentrate.

${ }^{2}$ Regression equation: $\mathrm{Y}=81.41-5.08 \mathrm{x}+1.04 \mathrm{x}^{2} ; \mathrm{r}^{2}=0.79$

${ }^{3}$ Regression equation: $\mathrm{Y}=4.88-0.30 \mathrm{x}+0.06 \mathrm{x}^{2} ; \mathrm{r}^{2}=0.79$.

Table 7 - Blood biochemical concentration of multiparous and primiparous lactating Saanen goats in grassland fed experimental concentrate

\begin{tabular}{|c|c|c|c|c|c|c|c|c|c|}
\hline \multirow[b]{2}{*}{$\mathrm{mg} \mathrm{dL}^{-1}$} & \multicolumn{5}{|c|}{ Level of calcium salts of fatty acids ${ }^{1}$} & \multirow{2}{*}{ SEM } & \multicolumn{3}{|c|}{ P-value } \\
\hline & $0.0 \%$ & $1.5 \%$ & $3.0 \%$ & $4.5 \%$ & $6.0 \%$ & & A & $\mathrm{L}$ & Q \\
\hline \multicolumn{10}{|c|}{ Multiparous } \\
\hline Glucose & 54.3 & 55.0 & 58.9 & 58.2 & 60.2 & 3.48 & 0.71 & 0.19 & 0.89 \\
\hline Cholesterol $^{2}$ & 75.0 & 93.6 & 103.3 & 99.30 & 110 & 6.38 & 0.02 & 0.003 & 0.24 \\
\hline Triglycerides & 25.5 & 20.1 & 24.5 & 24.3 & 25.6 & 3.06 & 0.71 & 0.66 & 0.45 \\
\hline Urea & 53.8 & 53.0 & 52.1 & 51.4 & 54.9 & 2.93 & 0.92 & 0.94 & 0.44 \\
\hline Calcium & 7.83 & 7.88 & 8.45 & 8.16 & 7.79 & 0.39 & 0.73 & 0.86 & 0.27 \\
\hline Phosphorus & 3.09 & 2.84 & 3.20 & 3.16 & 3.44 & 0.25 & 0.61 & 0.23 & 0.52 \\
\hline \multicolumn{10}{|c|}{ Primiparous } \\
\hline Glucose & 61.9 & 57.8 & 61.8 & 60.7 & & 3.03 & 0.77 & 0.99 & 0.64 \\
\hline Cholesterol $^{3}$ & 93.1 & 101 & 111 & 108 & & 4.58 & 0.10 & 0.03 & 0.28 \\
\hline Triglycerides & 23.2 & 26.0 & 26.0 & 28.2 & & 2.57 & 0.62 & 0.22 & 0.95 \\
\hline Urea & 53.7 & 51.0 & 53.2 & 52.1 & & 2.31 & 0.85 & 0.82 & 0.75 \\
\hline Calcium & 9.42 & 7.93 & 9.19 & 8.43 & & 0.51 & 0.25 & 0.49 & 0.50 \\
\hline Phosphorus & 3.23 & 3.51 & 3.93 & 3.65 & & 0.21 & 0.22 & 0.12 & 0.23 \\
\hline
\end{tabular}

SEM - standard error of the mean; A - ANOVA; L - linear; Q - quadratic.

${ }^{1}$ Level of calcium salts of fatty acids derived from soybean oil addition to the concentrate.

${ }^{2}$ Regression equation: $\mathrm{Y}=81.1+5.05 \mathrm{x} ; \mathrm{r}^{2}=0.81$.

${ }^{3}$ Regression equation: $\mathrm{Y}=95.0+3.80 \mathrm{x} ; \mathrm{r}^{2}=0.79$. 
According to the NRC (2007), for grazing multiparous goats with $57.00 \mathrm{~kg}$ body weight and $3.00 \mathrm{~kg} \mathrm{day}^{-1}$ milk yield, the metabolizable energy (ME) requirement for maintenance, production, and activity is $4.65 \mathrm{Mcal} \mathrm{day}^{-1}$. Grazing primiparous goats with $54.00 \mathrm{~kg}$ body weight and $2.70 \mathrm{~kg} \mathrm{day}^{-1}$ milk yield require $4.25 \mathrm{Mcal} \mathrm{day}^{-1} \mathrm{ME}$. The multiparous and primiparous goats in this study ingested 2.04 and $2.11 \mathrm{~kg} \mathrm{day}^{-1} \mathrm{DM}$, and the average values of ME in the diets were 2.53 and $2.54 \mathrm{Mcal} \mathrm{kg}^{-1}$, respectively. Thus, all energy requirements for maintenance, production, and activity were met (5.16 and $5.36 \mathrm{Mcal}^{\text {day }}{ }^{-1} \mathrm{ME}$ intake for multiparous and primiparous goats, respectively) and the goats were able to achieve the expected production. Also, the ME surplus of 0.51 and $1.11 \mathrm{Mcal} \mathrm{day}^{-1}$ for multiparous and primiparous goats, respectively, can be used for body weight gain.

The crude protein requirement was $281 \mathrm{~g} \mathrm{day}^{-1}$ for multiparous and $266 \mathrm{~g}$ day $^{-1}$ for primiparous goats; the crude protein intake was $295 \mathrm{~g}$ day $^{-1}$ and $298 \mathrm{~g}$ day $^{-1}$, respectively. Thus, according to the NRC (2007), the goats consumed more than the required amount of protein.

The digestibility coefficient of dry matter for multiparous and primiparous Saanen goats fed different levels of CSFA was $0.65 \mathrm{~g} \mathrm{~g}^{-1}$ and $0.64 \mathrm{~g} \mathrm{~g}^{-1}$, respectively. These values were close to the $0.63 \mathrm{~g} \mathrm{~g}^{-1}$ and $0.65 \mathrm{~g} \mathrm{~g}^{-1}$ observed by Silva et al. (2007) and Molina (2013), respectively; Silva et al. (2007), who fed goats Tifton hay (210 $\mathrm{g} \mathrm{kg}^{-1} \mathrm{CP}, 819 \mathrm{~g} \mathrm{~kg}^{-1}$ $\mathrm{NDF}$ ) and $500 \mathrm{~g} \mathrm{~kg}^{-1}$ CSFA from palm oil added to the diet; and Molina (2013), who fed goats with oat hay (78 $\mathrm{g} \mathrm{kg}^{-1}$ $\mathrm{CP}, 697 \mathrm{~g} \mathrm{~kg}^{-1} \mathrm{NDF}$ ) and $0,6.25,12.5,18.75$, or $25.0 \mathrm{~g} \mathrm{~kg}^{-1}$ DM of CSFA from soybean oil.

However, other authors have reported higher values for dry matter and nutrient digestibility, such as Sanz Sampelayo et al. (2002) and Souza et al. (2014), who showed $0.69 \mathrm{~g} \mathrm{~g}^{-1}$ DMD; Sanz Sampelayo et al. (2002), who fed goats alfalfa hay $\left(210 \mathrm{~g} \mathrm{~kg}^{-1} \mathrm{CP} ; 450 \mathrm{~g} \mathrm{~kg}^{-1}\right.$ $\mathrm{NDF}$ ) and 0,900 , or $1200 \mathrm{~g} \mathrm{~kg}^{-1} \mathrm{DM}$ of a rumen-inert fat in the concentrate; and Souza et al. (2014), who fed goats corn silage and $0,28.7,54.6$, or $80.5 \mathrm{~g} \mathrm{~kg}^{-1} \mathrm{DM}$ of CSFA. The higher digestibility of dry matter reported by Sanz Sampelayo et al. (2002) and Souza et al. (2014) may be related to the forages used. It is usually known that maize silage and alfalfa hay are more digestible than grass pastures or hay (oat and Tifton). Another reason could be the lower amount of CSFA in this study, which conferred a diet with lower energy values than those provided by Sanz Sampelayo et al. (2002) and Souza et al. (2014).

The positive linear effect on ether extract intake (EEI) for multiparous and primiparous lactating goats fed concentrate containing CSFA is explained by the ether extract (EE) content in the concentrate (Table 1). The addition of $15 \mathrm{~g}$ of CSFA to the concentrate increases the EE content to $11.8 \mathrm{~g} \mathrm{~kg}^{-1}$. This same positive linear effect was observed for the ether extract digestibility coefficient (EED). This effect may be associated with a higher concentration of unsaturated fatty acids in CSFA available in the intestine, which have higher solubility in micelles and are thus more digestible as compared with fatty acids with a higher degree of saturation (Palmquist and Mattos, 2011). The effect observed for EED contributed to the energy values of multiparous diets, which presented a quadratic effect with the addition of CSFA to the concentrate. The fact that ether extract provides 2.25 times more energy than carbohydrates and protein explains the improvement in the total digestibility of nutrients and increased energy availability for multiparous goats.

The addition of CSFA to the concentrate for multiparous and primiparous goats changed the neutral detergent fiber digestibility coefficient (NDFD); this result shows that forms of rumen-inert lipids cannot decrease cell wall digestibility, as previously shown by Sanz Sampelayo et al. (2002), Souza et al. (2014), and Molina (2013).

The proximity between the average organic matter digestibility $\left(0.67 \mathrm{~g} \mathrm{~g}^{-1}\right.$ for multiparous and $0.66 \mathrm{~g} \mathrm{~g}^{-1}$ for primiparous) and total digestible nutrients $\left(0.67 \mathrm{~g} \mathrm{~g}^{-1}\right.$ for multiparous and $0.67 \mathrm{~g} \cdot \mathrm{g}^{-1}$ for primiparous) showed that $n$-alkanes are a good marker to estimate dry matter intake and digestibility for grassland goats (Narvaez et al., 2012; Osoro et al., 2013).

Although the environmental conditions were not favorable for livestock grazing, the goats yielded close to the expected $3.00 \mathrm{~kg}$ day ${ }^{-1}$, i.e., the milk yields for multiparous and primiparous goats were 2.80 and $2.70 \mathrm{~kg}$ day $^{-1}$, respectively. This yield was achieved by the goats because, in addition to forage, the goats were fed $1.00 \mathrm{~kg} \mathrm{day}^{-1}$ of concentrate, and thus it was possible that the nutritional requirements were achieved and maintain the yield.

Goats with high milk yield need more nutrients, mainly energy, to support their high levels of productivity. When reared in grasslands, goats can reduce the time spent grazing and, consequently, reduce dry matter and energy intakes to maintain productivity. According to Ferrazza et al. (2012), Ribeiro et al. (2012), and Veloso Filho et al. (2013), the time spent grazing, ruminating, and resting normally changes according to the quality and quantity of forage. Furthermore, according to Silva et al. (2009), supplementation with concentrate can also change grazing behavior. Van Soest (1994) reported that the time spent ruminating is directly linked to neutral detergent fiber and the physical form of the diet. Thus, monitoring and 
understanding ruminant grazing behavior are essential to the efficient management of livestock systems.

The addition of CSFA to the concentrate for primiparous goats changed the time spent grazing; the estimated critical level, in other words, the shortest time spent grazing, was reached when the addition of CSFA was $2.5 \%$. Although the treatment decreased the time spent grazing, there was no effect on dry matter intake or milk yield in primiparous goats. This result is interesting when the time for grazing is a limiting factor for dry matter intake. With the estimated level of $2.5 \%$ CSFA for goats, even at a lower grazing time, the goats were able to eat the required amount of dry mater intake to maintain their production. Thus, further studies are needed to understand the real effect of CSFA in the feeding behavior of animals.

The structural and chemical properties of grass also can influence feeding behavior. Bratti et al. (2009) concluded that the structural characteristics, such as the mass of leaf blades and stems with sheaths, are a fundamental factor in animal grazing preference. Carvalho et al. (2006) evaluated different fiber levels in terms of the neutral detergent fiber in the forage and diet on the intake behavior of goats in lactation and concluded that feeding, ruminating, and total chewing times linearly increased with an increase in the neutral detergent fiber level in the diet. However, in this study, the grass structural characteristics did not change among the treatments, and the small amount of CSFA added to the concentrate did not influence grass intake behavior. Although all these factors interfere with feeding behavior, in this study, all the animals were raised under the same conditions, and so changes due to these factors were not observed.

The time spent on feed consumption was intercalated with one or more ruminating and resting periods. Therefore, multiparous goats dedicated $72 \%$ of their time to grazing, $17 \%$ to rumination, and $11 \%$ to resting. On the other hand, primiparous goats dedicated $78 \%$ of their time to grazing, $16.5 \%$ to rumination, and $5.5 \%$ to resting. The main reason why primiparous spend more time grazing is because they are smaller than multiparous goats $(54.0 \mathrm{~kg}$ vs. $57.0 \mathrm{~kg}$ ) and therefore should have a smaller rumen and to eat the same amount of dry mater the animals spent more time grazing. However, primiparous goats ate $106 \mathrm{~g} \mathrm{~kg}^{-1} \mathrm{DM}$ of $\mathrm{BW}^{0.75}$ (3.91\% of body weight), while multiparous goats ate $98.3 \mathrm{~g} \mathrm{~kg}^{-1} \mathrm{DM}$ of $\mathrm{BW}^{0.75}$ (3.58\% of body weight).

Furthermore, the greater amount of time dedicated to grazing and the lesser amount of time dedicated to resting by primiparous goats may be related to the need to recover body weight and the higher nutritional requirements of these animals, which, besides maintenance and production requirements, need nutrients for growth. Although primiparous goats had already reached the adult age (more than 24 months), they did not reach the average adult body weight of herd they came from (about $57 \mathrm{~kg}$ of adult body weight). Therefore, these animals supposedly increased their grazing and ruminating times to optimize their dry matter intake. However, the milk yields for multiparous and primiparous goats were similar, i.e., 2.8 and $2.7 \mathrm{~kg}^{\text {day }}{ }^{-1}$, respectively.

The values shown in this study for concentrations of glucose, cholesterol, and triglycerides in the blood serum for multiparous and primiparous goats were in the ranges described by Mundim et al. (2007). According to these authors, the reference values for glucose, cholesterol, and triglycerides should range between 50 and $75 \mathrm{mg} \mathrm{dL}^{-1}, 80$ and $130 \mathrm{mg} \mathrm{dL}^{-1}$, and 6 and $32 \mathrm{mg} \mathrm{dL}^{-1}$, respectively.

Therefore, the values obtained for serum glucose ( 54.35 to $61.94 \mathrm{mg} \mathrm{dL}^{-1}$ ) show that there was adequate glucose control, because the values are in agreement with the literature data (Canaes et al., 2009; Tanwar et al., 2000). Other studies have reported similar results when feeding goats diets containing CSFA. Molina (2013) evaluated the effect of adding CSFA to the diet of Saanen goats, with no observed interference with blood glucose, with an average of $50.98 \mathrm{mg} \mathrm{dL}^{-1}$. Similarly, Souza et al. (2014) did not observe changes in serum blood glucose when CSFA rich in polyunsaturated fatty acids was added to increase the dietary energy in the diet of Saanen goats.

The linear increase in blood cholesterol in multiparous Saanen goats fed CSFA may be related to the increased available fat in the diet, resulting in an increase in the cholesterol content for the biosynthesis of lipid proteins and transporters of lipids, thus stimulating the synthesis of cholesterol by enterocytes (Chilliard et al., 1986). This increase in the cholesterol content in response to feeding CSFA has been shown in the literature (Rapetti et al., 2009; Titti, 2011; Souza et al., 2014).

Addition of CSFA to the concentrate did not influence the blood triglyceride content in multiparous or primiparous goats, which averaged 23.98 and $25.83 \mathrm{mg} \mathrm{dL}^{-1}$, respectively. The absence of significant variation in plasma triglyceride levels is in agreement with previous results on lactating goats fed different levels and sources of lipids (Rapetti et al., 2009; Titti, 2011; Molina, 2013; Souza et al., 2014).

The average blood urea content was $53.02 \mathrm{mg} \mathrm{dL}^{-1}$ for multiparous goats and $52.48 \mathrm{mg} \mathrm{dL}^{-1}$ for primiparous goats. Although urea was at a higher concentration than that reported by Mejía et al. (2012), who suggested that the blood urea nitrogen (BUN) reference values should range between 10 and $21 \mathrm{mg} \mathrm{dL}^{-1}$ (equal to 21 to $45 \mathrm{mg} \mathrm{dL}^{-1}$ urea 
blood content), urea still remained within the range of 28 to $104 \mathrm{mg} \mathrm{dL}^{-1}$ observed by Mundim et al. (2007). Similar values have been reported by other authors when CSFA derived from soybean oil was added to the diet of lactating goats: Souza et al. (2014) observed values between 25 and $65 \mathrm{mg} \mathrm{dL}^{-1}$ and Molina (2013) observed values between 60 and $65 \mathrm{mg} \mathrm{dL}^{-1}$. The blood urea content recommended above is likely due to the lower availability of energy for the rumen bacteria and the excess dietary protein (discussed previously), which increases the ammonia nitrogen in the rumen fluid. This excess nitrogen in the rumen passes to the blood and is excreted in the milk and/or urine.

\section{Conclusions}

Addition of 3.5\% of calcium salts of fatty acids (35 g day $^{-1}$ ) increases the energy value of diets for multiparous grassland goats. Addition of calcium salts of fatty acids to the concentrate results in little effect on grazing time and does not change the nutritive value of diets for primiparous Saanen grassland goats. These results suggest that calcium salts of fatty acids are an alternative energy supplement for feeding lactating goats.

\section{Acknowledgments}

The authors thank Conselho Nacional de Desenvolvimento Científico e Tecnológico (CNPq) for the financial support (Project no. 475673/2010-7).

\section{References}

AOAC - Association of Official Analytical Chemists. 1990. Official methods of analysis. 15th ed. Association of Official Analytical Chemists, Gaithersburg, USA.

AOAC - Association of Official Analytical Chemists. 1998. Official methods of analysis. 16th ed. Association of Official Analytical Chemists, Gaithersburg, USA.

Baêta, F. and Souza, C. 1997. Ambiência em edificações rurais e conforto térmico. UFV, Viçosa, MG.

Baêta, F. C. and Souza, C. F. 2010. Ambiência em edificações rurais: conforto animal. Ed. UFV, Viçosa, MG.

Baldin, M.; Gama, M. A. S.; Dresch, R.; Harvatine, K. J. and Oliveira, D. E. 2013. A rumen unprotected conjugated linoleic acid supplement inhibits milk fat synthesis and improves energy balance in lactating goats. Journal of Animal Science 91:3305-3314.

Bratti, L. F. S.; Dittrich, J. R.; Barros, C. S.; Silva, C. J. A.; Monteiro, A. L. G.; Rocha, C. and Rocha, F. M. P. 2009. Ingestive behavior of goats in ryegrass and black oat pastures in pure or mixture culture. Ciência Animal Brasileira 10:397-405.

Branco, A. F.; Cecato, U.; Mouro, G. F. 2002. Avaliação técnicoeconômica da suplementação de vacas leiteiras em pastagem. p.123-142. In: II Sul-Leite: Simpósio sobre Sustentabilidadeda Pecuária Leiteira na Região Sul do Brasil. Santos, G. T.; Branco, A. F.;
Cecato, U.; Oliveira, E. and Parizotto, M. L. V., eds. Universidade Estadual de Maringá, Maringá.

Buffington, D. E.; Collazo-Arocho, A.; Canton, G. H.; Pitt, D.; Thatcher, W. W. and Collier, R. J. 1981. Black globe-humidity index (BGHI) as comfort equation for dairy cows. Transactions of the ASAE 24:711-714.

Canaes, T. S.; Negrão, J. A.; Paiva, F. A.; Zaros, M. and Delgado, T. F. 2009. Physiologic and productive responses of Alpine goats submitted to transportation to a new dairy location. Arquivo Brasileiro de Medicina Veterinária e Zootecnia 61:935-940.

Carvalho, G. G. P.; Pires, A. J. V.; Silva, H. G. O.; Veloso, C. M. and Silva, R. R. 2007. Methodological aspects of chewing activity of dairy goats fed cocoa meal or palm cake. Revista Brasileira de Zootecnia 36:103-110.

Carvalho, S.; Rodrigues, M. T.; Branco, R. H. and Rodrigues, C. A. F. 2006. Feeding behavior of lactating Alpine goats fed diets containing different dietary levels of forage neutral detergent fiber. Revista Brasileira de Zootecnia 35:562-568.

Chilliard, Y.; Morand Fehr, P.; Sauvant, D. and Bas, P. 1986. Utilisation metabolique des lipides par le ruminant en lactation. Bulletin Technique Centre de Recherches Zootechniques et Veterinaires de Theix.

Esmay, M. L. 1969. Principles of animal environment. Avi Publishing Company, Westport. 325p.

FAO - Food and Agriculture Organization. 2012. FAOSTAT: Production, Livestock Primary. Rome, Italy.

Ferrazza, J. M.; Migliorini, F.; Biezus, V.; Soares, A. B. and Silveira, A. L. F. 2012. Goat ingestive behavior on Alexadergrass (Urochloa (Syn. Brachiaria) plantaginea) under grazing intensities. Synergismus Scyentifica UTFPR 7(1).

Fonseca, C. E. M.; Valadares, R. F. D.; Valadares Filho, S. C.; Rodrigues, M. T.; Marcondes, M. I.; Porto, M. O.; Pina, D. S. and Moraes, K. A. K. 2006. Production of goats fed diets with increasing levels of protein: intake, milk yield and apparent digestibility. Revista Brasileira de Zootecnia 35:1162-1168.

Jenkins, T. C. and Palmquist, D. L. 1982. Effect of added fat and calcium on in vitro formation of insoluble fatty acid soaps and cell wall digestibility. Journal of Animal Science 55:957-963.

Mancilla-Leytón, J.; Vicente, A. M. and Delgado-Pertíñez, M. 2013. Summer diet selection of dairy goats grazing in a Mediterranean shrubland and the quality of secreted fat. Small Ruminant Research 113:437-445.

Mayes, R. W.; Lamb, C. S. and Colgrove, P. M. 1986. The use of dosed and herbage n-alkanes as markers for the determination of herbage intake. Journal of Agricultural Science 107:161-170.

Mejía, O. B.; Sánchez, F. A.; Noguera, R. R. and Ochoa, S. P. 2012. Efecto de la suplementación de ensilajes sobre perfiles metabólicos en cabras lactantes. Journal of Agriculture and Animal Sciences 1:26-37.

Molina, B. S. L. 2013. Efeitos da inclusão de gordura protegida nas rações de cabras Saanen em lactação. Dissertação (M. Sc.). Universidade Estadual de Maringá, Maringá.

Mundim, A.; Costa, A.; Mundim, S.; Guimarães, E. and Espíndola, F. 2007. Influence of parity and stage of lactation on the blood biochemical profile of Saanen goats. Arquivo Brasileiro de Medicina Veterinária e Zootecnia 59:306-312.

Narvaez, N.; Brosh, A. and Pittroff, W. 2012. Use of n-alkanes to estimate seasonal diet composition and intake of sheep and goats grazing in California chaparral. Small Ruminant Research 104:129-138.

NRC - National Research Council. 2001. Nutrient requirements of dairy cattle. 7th ed. National Academies Press, Washington, D.C. 
NRC - National Research Council. 2007. Nutrient requirements of small ruminants. National Academies Press, Washington, D.C.

Osoro, K.; Ferreira, L. M. M.; García, U.; Jáuregui, B. M.; Martínez, A.; Rosa García, R. and Celaya, R. 2013. Diet selection and performance of sheep and goats grazing on different heathland vegetation types. Small Ruminant Research 109:119-127.

Palmquist, D. L. and Mattos, W. R. S. 2011. Metabolismo de lipídeos. p.299-322. In: Nutrição de ruminantes. Berchielli, T. T.; Pires, A. V.; Oliveira, S. G., eds. FUNEP, Jaboticabal.

Peel, M. C.; Finlayson, B. L.; Mcmahon, T. A. 2007. Updated world map of the Köppen-Geiger climate classification. Hydrology and Earth System Sciences Discussions 4:439-473.

Rapetti, L.; Crovetto, G. M.; Galassi, G.; Sandrucci, A.; Succi, G.; Tamburini, A. and Battelli, G. 2009. Effect of maize, rumenprotected fat and whey permeate on energy utilisation and milk fat composition in lactating goats. Italian Journal of Animal Science $1: 43-54$.

Ribeiro, A. M.; Oliveira, M. E.; Silva, P. C.; Rufino, M. O. A.; Rodrigues, M. M. and Santos, M. S. 2012. Canopy characteristics, animal behavior and forage intake by goats grazing on Tanzaniagrass pasture with different heights. Acta Scientiarum Animal Sciences 34:371-378.

Rufino, M. O. A.; Alves, A. A.; Rodrigues, M. M.; Moura, R. L.; Cavalcante, A. C. R. and Rogério, M. C. P. 2012. Goat milk production and quality on Tanzania-grass pastures, with supplementation. Acta Scientiarum Animal Sciences 34:417-423.

Santos, G. T.; Assis, M. A.; Gonçalves, G. D.; Modesto, E. C.; Cecato, U.; Jobim, C. C. and Damasceno, J. C. 2000. Determination of in vitro digestibility of Cynodon grasses through different methods. Acta Scientiarum Animal Sciences 22:761-764.

Sanz Sampelayo, M. R.; Pérez, L.; Martín Alonso, J. J.; Gil Extremera, F. and Boza, J. 2002. Effects of concentrates with different contents of protected fat rich in PUFAs on the performance of lactating Granadina goats: Part I. Feed intake, nutrient digestibility, N and energy utilisation for milk production. Small Ruminant Research 43:133-139.

Silva, F. F.; Sá, J. F.; Schio, A. R.; Ítavo, L. C. V.; Silva, R. R. and Mateus, R. G. 2009. Grazing supplementation: availability and quality x supplementation levels x performance. Revista Brasileira de Zootecnia 38:371-389.

Silva, M. M. C.; Rodrigues, M. T.; Rodrigues, C. A. F.; Branco, R. H.; Leão, M. I.; Magalhães, A. C. M. and Matos, R. S. 2007. Effect of lipid supplementation on digestibility and ruminal metabolism in dairy goats. Revista Brasileira de Zootecnia 36:246-256.

Sirohi, S. K.; Walli, T. and Mohanta, R. K. 2010. Supplementation effect of bypass fat on production performance of lactating crossbred cows. Indian Journal of Animal Sciences 80:733-736.

Sniffen, C.; O'Connor, J.; Van Soest, P.; Fox, D. and Russell, J. 1992. A net carbohydrate and protein system for evaluating cattle diets: II. Carbohydrate and protein availability. Journal of Animal Science 70:3562-3577.

Souza, R.; Alcalde, C. R.; Hygino, B.; Molina, B. S. L.; Santos, G. T. and Gomes, L. C. 2014. Effects of dietary energy levels using calcium salts of fatty acids on nutritive value of diets and milk quality in peripartum dairy goats. Ciência e Agrotecnologia 38:286-294.

Tanwar, R.; Tinna, N.; Gahlot, A. and Sharma, S. 2000. Biochemical profile of clinical ketosis in goats. p.306-307. In: Proceedings of the 7 th International Conference on Goats, Tours, France.

Titti, H. 2011. Effects of varying levels of protected fat on performance of Shami goats during early and mid lactation.Turkish Journal of Veterinary and Animal Sciences 35:67-74.

Van Soest, P. J. 1994. Nutritional ecology of the ruminant. Cornell University Press, New York.

Van Soest, P. J.; Robertson, J. B. and Lewis, B. A. 1991. Methods for dietary fiber, neutral detergent fiber, and nonstarch polysaccharides in relation to animal nutrition. Journal of Dairy Science 74:3583-3597.

Veloso Filho, E. S.; Rodrigues, M. M.; Oliveira, M. E.; Rufino, M. O. A.; Câmara, C. S. and Garcez, B. S. 2013. Behavior of goats on palisade grass pasture under rotational stocking in two regrowth ages. Comunicata Scientiae 4:238-243.

Vulich, S. A.; Hanrahan, J. P. and Crowley, B. A. 1995. Modification of the analytical procedures for the determination of herbage and fecal n-alkanes used in the estimation of herbage intake. Journal of Agricultural Science 124:71-77. 